\title{
Therapeutic potential of essential oil of Melaleuca quinquenervia (Myrtaceae) in a rat model of ethanol- induced peptic ulcer
}

\author{
Ozlem T Cilingir-Kaya ${ }^{1 *}$, E Bihter Gurler ${ }^{2}$ \\ ${ }^{1}$ Istanbul Atlas University, School of Medicine, Department of Physiology. Atlas Vadi Kampusu, Anadolu Cd. No. 40 Kagithane, \\ ${ }^{2}$ Marmara University School of Medicine, Department of Histology and Embryology, Basibuyuk yolu sk, No. 9/1 Maltepe, \\ Istanbul. Turkey
}

${ }^{*}$ For correspondence: Email: tugce.cilingir@marmara.edu.tr

Sent for review: 11 September 2020

Revised accepted: 19 April 2021

\begin{abstract}
Purpose: To evaluate the effects of $M$. quinquenervia extract on ethanol-induced peptic ulcer in rats. Methods: The following three groups of $(n=6)$ Sprague Dawley rats were included in this study: vehicle $(C)$, ethanol-administered $(E)$ and ethanol $+M$. quinquenervia-treated (MQ). MQ group rats received $100 \mu \mathrm{g} / \mathrm{mL} \mathrm{M}$. quinquenervia essential oil just before $96 \%$ ethanol induction (1 ml/kg). One hour after ulcer induction, the animals were euthanized, and gastric and duodenal tissues were removed. Tissue samples were analysed for myeloperoxidase (MPO) activity, malondialdehyde (MDA), glutathione (GSH), myeloperoxidase (MPO) activity, malondialdehyde (MDA) and glutathione (GSH) levels, and histopathological examinations were performed by light microscopy.

Results: Gastric and duodenal GSH levels that decreased in the ethanol-administered ulcer groups ( $p$ $<0.001)$, rose following MQ treatment $(p<0.5)$. Moreover, elevated MPO and MDA levels $(p<0.5)$ in gastric tissues decreased after MQ-treatment. Similarly, the MQ-treated group showed recovery and control-like morphology compared to the ethanol group in both gastric and duodenal tissues when examined by microscopy.

Conclusion: The results indicate that $M$. quinquenervia extract has a positive impact on gastric injury in rats due to its antioxidant activity. Thus, the plant has a potential for the clinical management of gastric ulcer.
\end{abstract}

Keywords: Gastric ulcer, Melaleuca quinquenervia, Antioxidant, Histopathology

\begin{abstract}
This is an Open Access article that uses a fund-ing model which does not charge readers or their institutions for access and distributed under the terms of the Creative Commons Attribution License (http://creativecommons.org/licenses/by/4.0) and the Budapest Open Access Initiative (http://www.budapestopenaccessinitiative.org/read), which permit unrestricted use, distribution, and reproduction in any medium, provided the original work is properly credited.
\end{abstract}

Tropical Journal of Pharmaceutical Research is indexed by Science Citation Index (SciSearch), Scopus, International Pharmaceutical Abstract, Chemical Abstracts, Embase, Index Copernicus, EBSCO, African Index Medicus, JournalSeek, Journal Citation Reports/Science Edition, Directory of Open Access Journals (DOAJ), African Journal Online, Bioline International, Open-J-Gate and Pharmacy Abstracts

\section{INTRODUCTION}

Melaleuca quinquenervia is a small-to-mediumsized tree from the Myrtacae family. Its leaves are mostly used in the treatment of respiratory diseases [1]. The essential oil of this plant (Niaouli oil) is known for its medicinal properties in many tropical countries, including New Caledonia, Australia and Madagascar [2], and is often used to treat pain, dermatosis, influenza, rhinitis, sinusitis and pharyngitis in Africa [3,4].

Acute gastric injury is a very common problem of the gastrointestinal tract, affecting an average of 
4 million people per year. Its treatment is still being investigated [5]. Although Helicobacter pylori has a significant effect on the etiology and treatment of the disease, there is an increase in the incidence of gastric ulcers because of stress, alcohol consumption, and non-steroidal antiinflammatory drugs [6]. On the other hand, while omeprazole and similar anti-acid drugs, $\mathrm{H} 2$ receptor blockers, that are a class of gastric acidsuppressors like ranitidine and anticholinergics are frequently used in gastric diseases, they have many side effects and are insufficient to treat ulcer effectively [7].

Besides drugs, plant-derived natural products constitute a great potential remedy for gastric ulcer [8]. Several researches have shown that many natural products possess gastroprotective effects [9].

In the chemical analysis of Melaleuca quinquenervia, $31 \%$ had 1.8 cineole, $19.7 \%$ pcymen-8-ol, $16.5 \%$ p-cymene, $9.9 \%$ a-terpineol, $6.8 \%$ limonene, $4.2 \%$ a-pinene and $4.2 \%$ terpinolene. It was also found to have chemical components with known antioxidant properties [10]. The same study indicates that Melaleuca quinquenervia's essential oil at $100 \mu \mathrm{g} / \mathrm{mL}$ is a good antioxidant with a radical scavenging property of $84.3 \%$.

The constituents of Melaleuca quinquenervia offer a lot of benefits, including free-radical scavenging, anti-inflammatory, and antioxidant properties. Therefore, this study investigates the anti-inflammatory and anti-oxidants effects of this medical plant on a rat model of ethanol-induced peptic ulcer.

\section{EXPERIMENTAL}

\section{Animals}

Female Sprague-Dawley rats (200 - 250 g) were obtained from Marmara University School of Medicine Animal House, and kept under normal circumstances $(22 \pm 1 \circ \mathrm{C}, 65-70 \%$ humidity, $12 \mathrm{~h}$ light/dark cycle). The rats were fasted at night before the experiment day. All animal experiments were approved by the Marmara University School of Medicine Animal Care and Use Committee (approval no. 63.2019.mar), and the principles and guidelines developed by New York Academy of Sciences were followed [11].

\section{Chemicals}

Melaleuca quinquenervia essential oil was purchased from Art de Huile (Istanbul, Turkiye);
Ethanol (96\%) was purchased from Merck Millipore (MS, USA).

\section{Study design and treatments}

Female Sprague-Dawley rats $(n=18)$ that were not fed one day before the experiment day, were left overnight. On the experiment day, under the ether anaesthesia, randomly selected rats $(n=6)$ received orogastric saline (vehicle), ethanol (96 $\% ; 1 \mathrm{ml} / \mathrm{kg}$ ) and M. quinquenervia extract (100 $\mu \mathrm{g} / \mathrm{mL})+$ ethanol. One hour after administration, animals were euthanized. The stomach and duodenal tissues were dissected via greater curvature. The collected tissue samples were kept under $-80{ }^{\circ} \mathrm{C}$ for further assessments for myeloperoxidase (MPO) activity, malondialdehyde (MDA) and glutathione (GSH) levels, and also histopathological examinations at light microscopic level.

\section{Determination of malondialdehyde (MDA) and glutathione (GSH) levels and myeloperoxidase (MPO) activity}

Malondialdehyde levels show the products of lipid peroxidation. It was measured using a spectrophotometer at $532 \mathrm{~nm}$ by monitoring thiobarbituric acid-reactive chromogenic reagent formation, and results were expressed in $\mathrm{nmol} / \mathrm{g}$ [12]. Similar to MDA, GSH was determined spectrophotometrically with Ellman's reagent [13] Results were expressed as $\mu \mathrm{mol} \mathrm{GSH} / \mathrm{g}$ tissue. Azurophilic granules in the polymorphonuclear leukocytes (PMN) are found to be the primary site for myeloperoxidase (MPO) enzyme. Therefore, its activity is used for estimating neutrophil infiltration in inflammation. MPO activity was measured according to the spectrophotometric procedure reported by Hillegass et al [14]. The $460 \mathrm{~nm}$ absorbance was measured for $3 \mathrm{~min}$, and results were expressed as $\mathrm{U} / \mathrm{g}$ tissue.

\section{Macroscopical evaluation of ulcerative regions in stomach tissues}

Collected stomach tissue samples were examined in terms of the macroscopical appearance for ulcerative regions.

\section{Histological analysis}

After the decapitation of the animals, stomach and duodenum tissues were removed. For light microscopic examinations, the tissue samples were incubated in $10 \%$ formaldehyde solution for fixation, and then they underwent routine histological assessments (Leica, TP1020). Subsequently, fixed tissues dehydrated through 
ascending alcohol series (70, 90, 96, and 100\%) and cleared in xylene, then embedded in paraffin (Leica EG1150H+C). Approximately 4 - $5 \mu \mathrm{m}$ thick paraffin sections were manually cut on glass slides with a rotary microtome (Leica, RM2125RT) from the paraffin blocks, which include the tissues. Sections were dewaxed using xylene and then stained with hematoxylin and eosin (H \& E) for light microscopic imaging (Olympus DP72 attached to BX51, Tokyo, Japan). The stained sections were semiquantitatively scored using 0-3 scoring system (0: none, 1: mild, 2: moderate, 3: severe) according to the modified criteria from the previous study [18]. For the stomach tissues, desquamation of surface epithelium, haemorrhage/congestion, degeneration of glandular cells, inflammatory cell infiltration were used as evaluation criteria with the highest score of 12. Semi-quantitative score was also obtained for duodenal tissues, with the highest score being 15, due to the inclusion of the degeneration of the villus morphology analysis to the evaluation.

\section{Statistical analysis}

GraphPad Prism 8.1 (GraphPad Software, San Diego, CA) was used for statistical analysis. The results are expressed as mean \pm SEM. Analysis of variance (ANOVA) followed by Tukey's multiple comparison tests was performed to determine statistically significant difference between the groups. Values of $p<0.05$ were regarded as statistically significant.

\section{RESULTS}

\section{Malondialdehyde (MDA) and glutathione (GSH) levels, and myeloperoxidase (MPO) activity}

Ethanol administration resulted in the depletion of gastric and duodenal GSH levels ( $p<0.001)$, while $M$. quinquenervia treatment reversed this depletion significantly $(p<0.5)$ (Figure 1 a and b). Increase in MPO activity of gastric mucosa ( $p$ $<0.05)$ diminished significantly with the Melaleuca quinquenervia treatment $(p<0.01)$ (Figure $1 \mathrm{c}$ ). Increase in MPO activity in the duodenum was not significant in all groups (data not shown). Similar to MPO activity, MDA levels of gastric tissue elevated significantly (Figure 1 d) $(p<0.05)$. Treatment with Melaleuca quinquenervia tends to reduce this elevation. However, MDA level of the Melaleuca quinquenervia-treated group was not different from the vehicle-treated group.
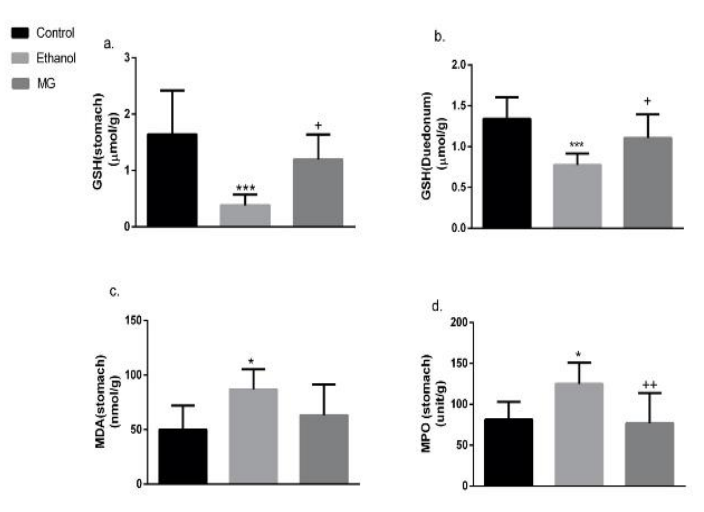

Figure 1: Malondialdehyde (MDA) and glutathione (GSH) levels and myeloperoxidase (MPO) activity of gastric tissues and GSH level for duodenal tissue. Data are expressed as mean \pm SEM; $(n=6)$; ${ }^{*} p<$ $0.05,{ }^{* *} p<0.01,{ }^{* * *} p<0,001$ vs vehicle group; ${ }^{+} p<$ $0.05,{ }^{++} p<0.01$ vs ethanol-treated group

\section{Macroscopic and histological evaluations}

The results of the macroscopic evaluation of the ulcerative regions show that while the ethanol group showed severe ulcerative areas in the stomach, the $M$. quinquenervia-treated group displayed normal macroscopic morphology (Figure 2).

Light microscopic examination and semiquantitative scores of the stomach tissues showed that the vehicle group had regular gastric pits with normal epithelial lining and proper glandular structures (Figure 3a). In the ethanol group, severe vascular congestion, glandular cell degeneration, damaged epithelial lining, and inflammatory cell infiltration were seen as signs of the ulcer (Figure $3 \mathrm{~b}$ and $\mathrm{c}$ ).

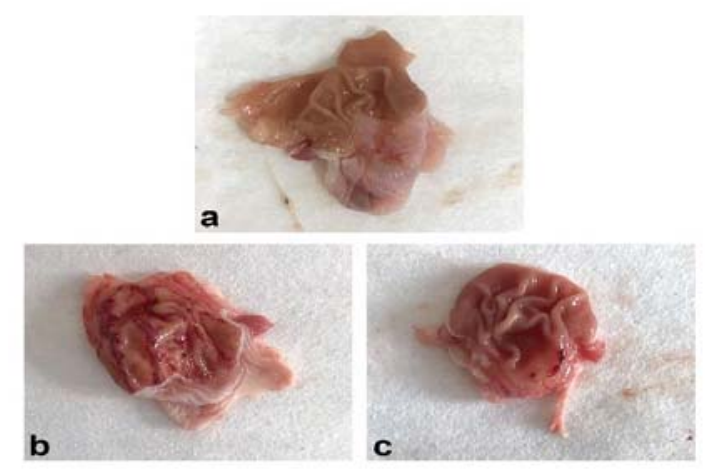

Figure 2: Macroscopic appearance of the stomach tissues. (a) Vehicle group with regular stomach tissue; (b) Ethanol group (acute gastric injury/ulcer) with severe ulcerative regions; (c) Melaleuca quinquenervia-treated group with appearance similar to that of control 

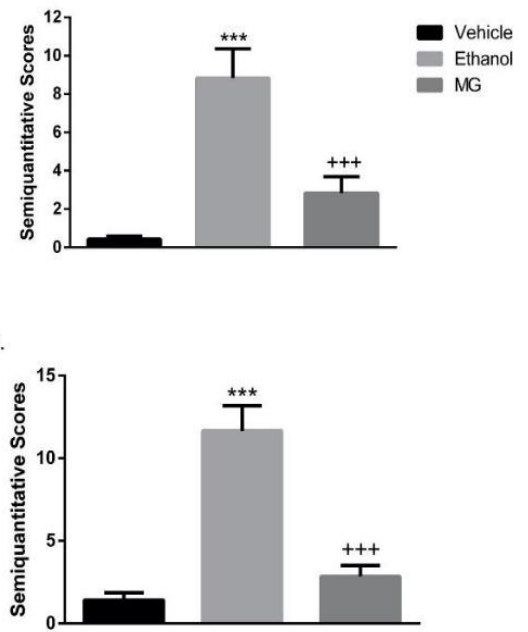

Figure 3: Semiquantitative histopathological scores for stomach (a) and duodenal (b) tissues. Data are expressed as mean \pm SEM; $(n=6) ;{ }^{* * *} p<0,001$ vs vehicle group; ${ }^{+++} p<0.001$, vs ethanol-treated group

Stomach tissues from the $M$. quinquenerviatreated group showed control-like appearance and all the parameters, which are the indicatives of ulcer, were regressed (Figure $3 \mathrm{~d}$ ). The statistical analysis of the semi-quantitative scores supported the histological findings. The total score of the ethanol group were observed to have significantly increased when compared with the vehicle group $(p<0.001)$, whereas the $M$. quinquenervia-treated group had decreased total score $(p<0.001)$, suggesting recovery of the ulcerative regions (Figure 4 a).
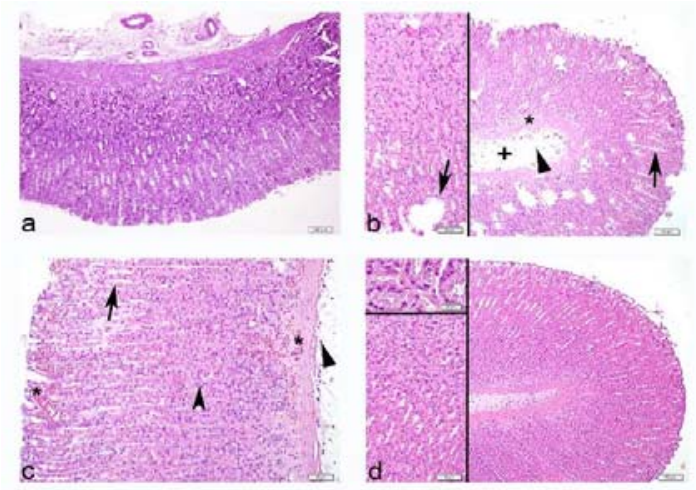

Figure 4: Photomicrographs of stomach tissues from the experimental groups. a. Vehicle group, b and c. Ethanol group (acute gastric injury/ulcer), d. Melaleuca quinquenervia-treated group. Arrow: Epithelial degeneration, arrowhead: asterisk (*): Vascular congestion, plus (+): Damage in the tunica adventitia (Hematoxyline and Eosin staining, Bars: $100 \mu \mathrm{m}$ for $\mathrm{x} 100 ; 50 \mu \mathrm{m}$ for $\mathrm{x} 200$ and $20 \mu \mathrm{m}$ for $\mathrm{x} 400$ magnification)
The duodenal tissues showed regular villi organisation with proper epithelial lining (Figure 5 a). For all the evaluation criteria, significant increases were seen in the ethanol group, compared to the vehicle group $(p<0.001)$ (Figure $5 \mathrm{~b}$ and $\mathrm{c}$ ). Control-like histological appearance was noticed in the M. quinquenerviatreated group (Figure $5 \mathrm{~d}$ ), significantly $(p<$ 0.001) (Figure $4 \mathrm{~b}$ ).
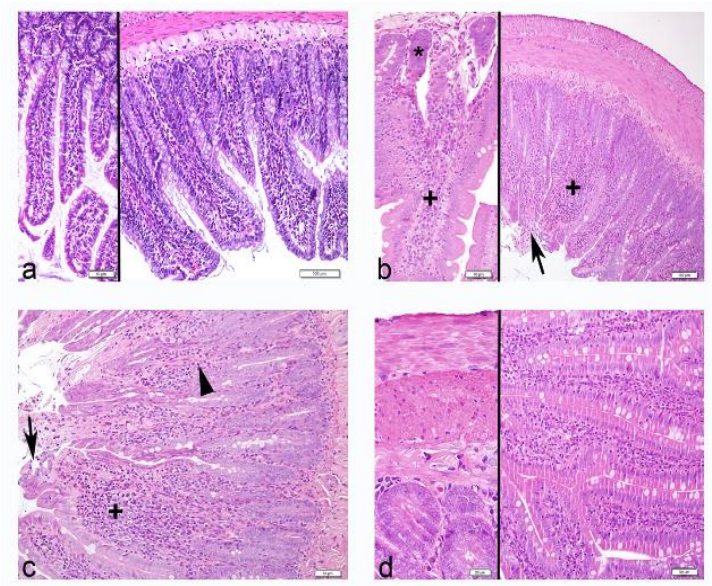

Figure 5: Photomicrographs of duodenal tissues from the experimental groups. a. Vehicle group, b and c. Ethanol group (acute gastric injury/ulcer), d. Melaleuca quinquenervia-treated group. Arrow: Epithelial degeneration, arrowhead: inflammatory cell infiltration, asterisk $\left({ }^{*}\right)$ : degenerated glandular structure, plus (+): Villi with irregular morphology. (Hematoxyline and Eosin staining., Bars: $100 \mu \mathrm{m}$ for $\mathrm{x} 100 ; 50 \mu \mathrm{m}$ for $\mathrm{x} 200$ and $20 \mu \mathrm{m}$ for $\times 400$ magnification)

\section{DISCUSSION}

Gastric mucosa has many natural defence mechanisms for preventing the damage caused by noxious agents. Histological and biochemical findings of this present study revealed that oxidative stress injury induced by ethanol was reversed by Melaleuca quinquenervia treatment. Stomach GSH levels, which decreased in ethanol-treated rats, were preserved when the rats received Melaleuca quinquenervia treatment. Neutrophil accumulation, identified by MPO activity, decreased markedly when the animals were treated with Melaleuca quinquenervia. Similar to MPO, MDA levels also tended to decrease in Melaleuca quinquenervia treated animals. Concomitant to biochemical findings, gastric damage was also significantly diminished by Melaleuca quinquenervia treatment, as assessed via histological scores. All these findings suggest that Melaleuca quinquenervia treatment has potent antiinflammatory and anti-oxidative effects on the damaged gastric mucosa. 
Since previous reports showed the role of reactive oxygen species (ROS) in the pathophysiology of gastric mucosal damage [16], natural antioxidants are found to be beneficial, by protecting the stomach or by expediting the healing of mucosal damage [17]. Chemical studies reported that Melaleuca quinquenervia leaves contain triterpenoids, flavanones and polyphenols [18]. Past reports indicated that triterpenoids [19], flavanones [20] and polyphenolics [21] have antioxidant and antiinflammatory effects. On the contrary, one report revealed that Melaleuca quinquenervia does not have an anti-inflammatory effect [22]

In agreement previous reports, the results of the present study showed that Melaleuca quinquenervia treatment markedly inhibited GSH depletion, implying a reduction in lipid peroxidation that prevents gastric damage. GSH is the prime defence against oxidative damage [23]. Oxidative stress causes a fast depression of GSH content of the cell. The current findings demonstrate that GSH decrease was preserved by Melaleuca quinquenervia. Additionally, MPO activity, a marker of inflammation, mostly increases ulcerations [24] also diminished by Melaleuca quinquenervia treatment, while increase in the other inflammation marker, MDA, was limited. Likewise, healing of ulcer histologically revealed the anti-inflammatory effect of the extract.

\section{CONCLUSION}

The findings of this study indicate that Melaleuca quinquenervia has gastro-protective effects in rats due to its anti-inflammatory and antioxidant properties. Thus, Melaleuca quinquenervia extract may hay also exhibit similar properties in humans. However, further investigations are required to understand the mechanism of the plant's antioxidant and anti-inflammatory properties.

\section{DECLARATIONS}

\section{Acknowledgement}

We would like to thank our colleague, Dr Dilek Ozbeyli, for his assistance during the experimental work and data analyses.

\section{Conflict of interest}

No conflict of interest is associated with this work.

\section{Contribution of authors}

We declare that this work was done by the authors named in this article, and all liabilities pertaining to claims relating to the content of this article will be borne by the authors. The authors who conceived and designed the study; Ozlem T. Cilingir-Kaya, E. Bihter Gurler. The persons who collected and analysed the data; Ozlem T. Cilingir-Kaya, E. Bihter Gurler. The persons who wrote the manuscript as well as an indication that all authors read and approved the manuscript for publication; Ozlem T. Cilingir-Kaya, E. Bihter Gurler.

\section{Open Access}

This is an Open Access article that uses a funding model which does not charge readers or their institutions for access and distributed under the terms of the Creative Commons Attribution License (http://creativecommons.org/licenses/by/ 4.0) and the Budapest Open Access Initiative (http://www.budapestopenaccessinitiative.org/rea d), which permit unrestricted use, distribution, and reproduction in any medium, provided the original work is properly credited.

\section{REFERENCES}

1. Stablein JJ, Bucholtz GA, Lockey RF. Melaleuca tree and respiratory disease. Ann Allergy Asthma Immunol 2002;89(5):523-530.

2. Cock IE, Winnett V, Sirdaarta J, Matthews B. The potential of selected Australian medicinal plants with anti-Proteus activity for the treatment and prevention of rheumatoid arthritis. Pharmacogn Mag 2015;11(Suppl 1): S190-208.

3. Acha E, Aikpe JFA, Adoverlande J, Assogba MF, Agossou G, Sezan A, Dansou HP and JGbenou JD. Anti-inflammatory Properties of Melaleuca Quinquenervia (Cav.) ST Blake Myrtaceae (Niaouli) Leaves' Essential Oil. Journal of Chemical and Pharmaceutical Research. 2019; 11(1):36-50.

4. Gbenou JD, Moudachirou M, Chalchat J-C, Figuérédo G. Chemotypes in Melaleuca quinquenervia (Cav.) S.T. Blake (Niaouli) from Benin Using Multivariate Statistical Analysis of Their Essential Oils. Journal of Essential Oil Research2007;19(2):101-104.

5. Chung KT, Shelat VG. Perforated peptic ulcer - an update. World J Gastrointest Surg. 2017;9(1):1-12.

6. Groenen MJ, Kuipers EJ, Hansen BE, Ouwendijk RJ. Incidence of duodenal ulcers and gastric ulcers in a Western population: back to where it started. Can J Gastroenterol. 2009;23(9):604-608.

7. Kinoshita $Y$, Ishimura N, Ishihara S. Advantages and Disadvantages of Long-term Proton Pump Inhibitor Use. J Neurogastroenterol Motil. 2018;24(2):182-196.

Trop J Pharm Res, May 2021; 20(5): 985 
8. Repetto MG, Llesuy SF. Antioxidant properties of natural compounds used in popular medicine for gastric ulcers. Braz J Med Biol Res. 2002;35(5):523-534.

9. Solmaz A, Sener G, Cetinel S, Yüksel M, Yeğen $C$, Yeğen BC. Protective and therapeutic effects of resveratrol on acetic acid-induced gastric ulcer. Free Radic Res. 2009; 43(6):594-603.

10. Siddique S, Sania M, Firdaus-e-Bareen, Zahida P. Chemical characterization, antioxidant and antimicrobial activities of essential oil from Melaleuca quinquenervia leaves. Indian J Exp Bio. 2018;56(9):686-693.

11. Institute of Medicine (US); National Research Council (US). International Animal Research Regulations: Impact on Neuroscience Research: Workshop Summary. Washington (DC): National Academies Press (US); $2012 . \quad$ Available from: https://www.ncbi.nlm.nih.gov/books/NBK97817/ doi: 10.17226/13322

12. Casini AF, Ferrali M, Pompella A, Maellaro E, Comporti M. Lipid peroxidation and cellular damage in extrahepatic tissues of bromobenzene-intoxicated mice. Am J Pathol. 1986;123(3):520-531.

13. Ernest B. Reduced Glutathione (GSH). 2nd Edition ed. New York: Grune and Stratton; 1975. 160 p.

14. Hillegass $L M$, Griswold $D E$, Brickson B, AlbrightsonWinslow C. Assessment of myeloperoxidase activity in whole rat kidney. I Pharmacol Methods. 1990;24(4):285-295.

15. Gürler EB, Çilingir-Kaya Ö T, Peker Eyüboglu I, Ercan F, Akkiprik M, Reiter RJ, et al. Melatonin supports alendronate in preserving bone matrix and prevents gastric inflammation in ovariectomized rats. Cell Biochem Funct. 2019;37(2):102-112.

16. Yoshikawa T, Naito Y, Ueda S, Oyamada H, Takemura $T$, Yoshida $N$, et al. Role of oxygen-derived free radicals in the pathogenesis of gastric mucosal lesions in rats. $J$ Clin Gastroenterol. 1990;12 Suppl 1: S65-71.

17. Naito $Y$, Yoshikawa $T$, Matsuyama $K$, Yagi N, Arai $M$, Nakamura $Y$, et al. Effects of oxygen radical scavengers on the quality of gastric ulcer healing in rats. J Clin Gastroenterol. 1995;21 Suppl 1: S82-6.

18. Lee TH, Wang GJ, Lee CK, Kuo YH, Chou CH. Inhibitory effects of glycosides from the leaves of Melaleuca quinquenervia on vascular contraction of rats. Planta Med. 2002;68(6):492-496.

19. Amoussa AM, Lagnika L, Bourjot M, VonthronSenecheau C, Sanni A. Triterpenoids from Acacia ataxacantha $D C$ : antimicrobial and antioxidant activities. BMC Complement Altern Med. 2016;16(1):284.

20. Yoshimura $M$, Ito $H$, Miyashita $K$, Hatano $T$, Taniguchi $S$, Amakura $Y$, et al. Flavonol glucuronides and $C$ glucosidic ellagitannins from Melaleuca squarrosa. Phytochemistry. 2008; 69(18):3062-9.

21. Yoshimura M. [Structure elucidation of antioxidative polyphenols and their biological properties]. Yakugaku Zasshi 2014; 134(9):957-64.

22. Aboutabl EA, Abdelhakim G, Moharram FA. A Study of Some Pharmacodynamic Actions of Certain Melaleuca Species Grown in Egypt. Journal of Essential Oil Research. 1996; 10(4):345-7.

23. Ross $D$. Glutathione, free radicals and chemotherapeutic agents. Mechanisms of free-radical induced toxicity and glutathione-dependent protection. Pharmacol Ther. 1988; 37(2):231-49.

24. Souza MH, Lemos HP, Oliveira RB, Cunha FQ. Gastric damage and granulocyte infiltration induced by indomethacin in tumour necrosis factor receptor 1 (TNFR1) or inducible nitric oxide synthase (iNOS) deficient mice. Gut. 2004; 53(6):791-6. 